IP Periodica Polytechnica Civil Engineering

\author{
60(1), pp. $11,20,2016$ \\ DOI: $10.3311 / P P c i .7923$ \\ Creative Commons Attribution (1) \\ RESEARCH ARTICLE
}

\section{The Dangerous Condition of Ground during High Overburden Tunneling (A Case Study in Iran)}

\author{
Raheb Bagherpour, Mohammad Javad Rahimdel
}

Received 19-01-2015, revised 31-05-2015, accepted 22-06-2015

\begin{abstract}
Knowledge of the ground condition and its hazards can play an important role in the selection of support and suitable excavation method in underground structures. Water transport tunnel is one of the most important structures with regard to the goal of excavation, special conditions and limitations considered in the design and execution of them. Beheshtabad Water Conveyance Tunnel with 64930 meters length, 6 meters final diameter is the largest water Conveyance tunnel in Iran. Because of high over burden and weak rock in the most of tunnel path, the probable hazardous of the ground condition such as squeezing and rock burst must be studied. Squeezing stands for large timedependent convergence during tunnel excavation. This phenomenon occurs in weak rocks and deep conditions. Besides, the height of overburden in some of the zone tunnel is about 1200 meters. The occurrence of this phenomenon is always together with the instantaneous release of strain energy stored in the rock materials, causing the harm to the personal equipment and the collapse of underground structures. The existence of high thickness overburden in some the zones of this project indicates the high potential of rock burst hazard. In this research, the length of the tunnel has been partitioned into sections using the interpreted geological, geophysical studies and borehole data. After evaluating rock burst and squeezing potential with alternative analytical and experimental methods for each section, the results of different methods were compared with each other. Results predict low to moderate squeezing potential and moderate to high rock burst potential for some panels of the tunnel.
\end{abstract}

\section{Keywords}

Central plateau of Iran · Dangerous condition of ground $\cdot$ rock burst · squeezing · Beheshtabad Water Conveyance Tunnel

\section{Raheb Bagherpour}

Department of Mining Engineering, Isfahan University of Technology, Isfahan 8415683111, Iran

e-mail: bagherpour@cc.iut.ac.ir

\section{Mohammad Javad Rahimdel}

Department of Mining Engineering, Sahand University of Technology, Tabriz 5331711111, Iran

e-mail: m_rahimdel@sut.ac.ir

\section{Introduction}

Tunnels are one of the vital arteries that, because of excessive expenses spent for their introduction and also derangement of passing traffic as a result of perfect demolition or serious damages, need the observation of technical geotechnical considerations in design and performance. Zayandehrud River is the only permanent river in the Central Plateau of Iran. Water demand in this area is constantly growing due to population growth, key industries, withdrawal of ground water tables and reduction of its quality. So, Beheshtabad Tunnel, by transporting 1070 millions of cube meters of water per year to Iran central plateau, is considered in order to eliminate the shortages in the parts of drinking water, industry and agriculture. This plan, consisting of a dam with 184 meters height and water transport tunnel with the length of about $65 \mathrm{~km}$ and 6 meters diameter, is expected to be the longest water transport tunnel in Iran.

In this research, firstly, the tunnel was panelled by using the interpretation of geological, geophysical studies and boreholes. Then, the squeezing and rock burst potential were studied through empirical and analytical methods for each panel. Finally, the results were compared with each other.

\subsection{Literature Review}

The rock burst and squeezing are two main modes of underground instability caused by overstressing of the ground. Both modes are generally related to continuous ground. Squeezing can occur both in massive (weak and deformable) rocks and in highly jointed rock masses as a result of overstressing. It is characterized by yielding under the redistributed state of stress during and after excavation [1]. The squeezing can be very large; deformations as much as $17 \%$ of the tunnel diameter have been reported in India [2]. According to the unexpected geotechnical hazards during tunnelling, Singh et al., Goel et al., Jethwa et al., Hoek and Marinos have studied the squeezing phenomenon for deep tunnels in weak rocks and derived some criteria to recognize it [2-6].

In most criteria, the overburden load plays an important role in developing the squeezing conditions. Furthermore, when an excavation for a deep underground tunnel or chamber is under- 
taken in a strong and brittle rock, the change in stress results in dynamic damage to the adjacent rock. This is referred to as rockburst or break ways. Such rock bursts are a major hazard for the safety of engineers and engineering equipment, as well as affecting the shape/size of the structure [7]. Hoek and Brown, Myrvang and Grimstad, Hatcher, Haramy, Qiao and Tian, Wang and Park and Amberg have been working to identify rock burst in deep tunnels with brittle rocks [8,-14].

\section{Beheshtabad Water Conveyance Tunnel}

Beheshtabad Water Conveyance Tunnel, about 65 kilometre length and 6 meter width, is one of the biggest water supplying projects for transporting water to the central plateau of Iran. This tunnel is located near Ardal City with east north-west south direction. From the entrance to $17 \mathrm{~km}$ of the tunnel, it is located in Zagros Zone and its output is in Sanandaj-Sirjan Zone. This tunnel is expected to transfer water to resolve water deficiencies and shortcomings for industrial and agricultural use in the central plateau of Iran, 1070 cubic million meters annually [15].

Most important problems in the path of this tunnel refer to its cross within numerous fractures, resulting in many problems and troubles during drilling and in the stages of maintenance coverage of tunnel.

With regard to 19 boreholes in the tunnel path, tunnel has been panelled to 16 sections. Engineering geological properties for each panel are summarized in Table 1 . The rock engineering classification is shown in Table 2[16].

Referring to Table 1 it can be seen that the classification grading by $Q$ system is lower than that by the RMR for the same type rock. That is because $Q$ system takes the high stress field into consideration, and to some extent, it causes the rock mass instability.

Regarding researches in the studied area, stability analysis and leakage quantity investigation have been conducted. Rahimdel and et al. proposed the primary support for tunnel section based on geology section and rock masses of the tunnel using RMR, Q and VNIMI methods. The results based on VNIMI method are given in Table 3 [17].

Rafiee and et al. [15] used the Fuzzy Analytical Hierarchy Process (FAHP) to support the estimation of tunnel. In this study, regarding the numerical analysis (finite difference program FLAC2D), six support systems were considered as the decision alternative are shown in Table 4 and support cost, factor of safety, applicability, time, displacement and mechanization were considered as the criteria. Calculations showed that the alternative "E" should be selected as the optimum support system to satisfy the goals and objectives of Behashtabad Tunnel.

\section{Squeezing}

The magnitude of tunnel convergence, the rate of deformation and the extent of the yielding zone around the tunnel depend on the geological and geotechnical conditions, the in-situ state of stress relative to rock mass strength, the groundwater flow and pore pressure, and the rock mass properties [18]. The increase in movement velocity and displacement magnitude often vary in the tunnel face depending on geological conditions, the principal stress orientations and the tunnel shape [19]. Squeezing is, therefore, synonymous with yielding and time-dependence; its cost depends on the excavation and support techniques adopted. If the support installation is delayed, the rock mass moves into the tunnel and stress redistribution take place around it. On the contrary, if deformation is restrained, squeezing will lead to long-term load build-up of rock support.

For the evaluation of the potential of squeezing, empirical and semi-empirical methods have been introduced via deferent researchers. These methods are explained below.

\subsection{Prediction of Squeezing}

\subsubsection{Empirical Approaches}

The empirical approaches are essentially based on classification schemes. Two of these approaches are mentioned below in order to illustrate the uncertainty still surrounding the subject, notwithstanding its importance in the tunnelling practice.

3.1.1.1 Singh et al. Approach This method, which is based on the results of 39 case histories, by collecting data on rock mass quality $Q$, overburden and height, proposes that squeezing potential is predictable by using Eq. (5) and Table 5[2].

$$
H=350 Q^{1 / 3}
$$

Where $H$ is the overburden and $Q$ is the rock mass quality classification.

3.1.1.2 Goel et al. approach A simple empirical approach developed by Goel et al. is based on the rock mass number $\mathrm{N}$, which is defined as stress-free $Q$ as follows [3].

$$
N=(Q)_{S R F=1}
$$

Where $N$ is the rock mass number, $(Q)_{S R F=1}$ is rock mass quality classification with $S R F$ equals to 1 and $S R F$ is stress reduction factor.

This is used to avoid the problems and uncertainties in obtaining the correct rating of parameter SRF in Barton et al. $Q$. Considering the tunnel depth $\mathrm{H}$, the tunnel span or diameter $\mathrm{B}$, and the rock mass number $\mathrm{N}$ from 99 tunnel sections, Goel et al. plotted the available data on a log-log diagram (Fig. 1), between $N$ and $H \times B^{0.1}[3]$.

\subsubsection{Semi-Empirical Approaches}

The common starting point of all these methods for quantifying the squeezing potential of rock is the use of the "competency factor", which is defined as the ratio of uniaxial compressive strength of rock/rock mass to overburden stress. Two of such methods are briefly discussed below. 
Tab. 1. Rock engineering geological characteristics for each tunnel section [16]

\begin{tabular}{|c|c|c|c|c|c|c|}
\hline Section & $\begin{array}{l}\text { Kilometer } \\
(\mathrm{m})\end{array}$ & Rock mass & $\begin{array}{l}\text { Overburden } \\
(\mathrm{m})\end{array}$ & $\begin{array}{l}\text { Density } \\
\left(\mathrm{gr} / \mathrm{cm}^{3}\right)\end{array}$ & UCS (MPa) & RQD \\
\hline 1 & $5941-7800$ & $\begin{array}{c}\text { Limestone } \\
\text { with dolomite }\end{array}$ & 600 & 2.530 & $65-75$ & $95-100$ \\
\hline II & $7800-8116$ & Marl stone & 781.58 & 2.968 & $20-40$ & $95-100$ \\
\hline III & $8116-10790$ & $\begin{array}{l}\text { Lime stone } \\
\text { and Marl } \\
\text { stone }\end{array}$ & 1205.5 & 2.509 & $65-75$ & $95-100$ \\
\hline IV & $\begin{array}{c}10790- \\
12129\end{array}$ & $\begin{array}{l}\text { Marl stone } \\
\text { and con- } \\
\text { glomerate }\end{array}$ & 340 & 2.488 & $70-90$ & $95-100$ \\
\hline V & $\begin{array}{c}12129- \\
15492\end{array}$ & $\begin{array}{l}\text { Mud stone } \\
\text { and con- } \\
\text { glomerate }\end{array}$ & 294 & 2.450 & $30-45$ & $95-100$ \\
\hline VI & $\begin{array}{c}15492- \\
17574\end{array}$ & $\begin{array}{l}\text { Weathered } \\
\text { and altered } \\
\text { andesitic }\end{array}$ & 285 & 2.491 & $20-30$ & $50-60$ \\
\hline VII & $\begin{array}{c}17574- \\
18013\end{array}$ & $\begin{array}{l}\text { Crushed } \\
\text { limestone } \\
\text { and Marly }\end{array}$ & 327 & 2.651 & $20-40$ & $40-50$ \\
\hline & & limestone & & & & \\
\hline VIII & $\begin{array}{l}18013- \\
20862\end{array}$ & $\begin{array}{l}\text { Marly and } \\
\text { shale } \\
\text { limestone }\end{array}$ & 349 & 2.464 & $20-30$ & $50-85$ \\
\hline IX & $\begin{array}{c}20862- \\
21730\end{array}$ & $\begin{array}{l}\text { Marl and } \\
\text { Shale }\end{array}$ & 477 & 2.733 & $25-35$ & $85-90$ \\
\hline$x$ & $\begin{array}{c}21730- \\
24174\end{array}$ & $\begin{array}{c}\text { Marl and } \\
\text { Shale }\end{array}$ & 621 & 2.646 & $20-40$ & $85-90$ \\
\hline$X I$ & $\begin{array}{c}24174- \\
29030\end{array}$ & $\begin{array}{c}\text { Alteration of } \\
\text { massive } \\
\text { limestone }\end{array}$ & 654.45 & 2.646 & $40-50$ & $75-85$ \\
\hline XII & $\begin{array}{c}29030- \\
31604\end{array}$ & $\begin{array}{c}\text { Shaly } \\
\text { limestone }\end{array}$ & 381 & 2.651 & $25-60$ & $25-60$ \\
\hline XIII & $\begin{array}{c}31604 \text { - } \\
34912\end{array}$ & $\begin{array}{l}\text { Melonitic } \\
\text { limy sand } \\
\text { stone with } \\
\text { quarts } \\
\text { lenses }\end{array}$ & 335.6 & 2.667 & $10-30$ & $25-45$ \\
\hline XIV & $\begin{array}{c}34912- \\
37490\end{array}$ & $\begin{array}{c}\text { Melonitic } \\
\text { limy sand } \\
\text { stone with } \\
\text { quarts } \\
\text { lenses }\end{array}$ & 481 & 2.690 & $25-50$ & $25-50$ \\
\hline$X V$ & $\begin{array}{c}37490- \\
37892\end{array}$ & $\begin{array}{l}\text { Limestone } \\
\text { and dolomite }\end{array}$ & 571 & 2.690 & $50-80$ & $90-100$ \\
\hline
\end{tabular}


Tab. 2. Table 2 Rock engineering classification of the studied tunnel [16]

\begin{tabular}{|c|c|c|c|c|}
\hline \multirow{2}{*}{ Tunnel Section } & \multicolumn{2}{|c|}{ RMR } & \multicolumn{2}{|c|}{ Q } \\
\hline & Value & Rating & Value & Rating \\
\hline 1 & $54-55$ & Fair & $1.65-2.67$ & Poor \\
\hline II & $60-64$ & Good & $1.35-4$ & Poor \\
\hline III & $53-60$ & Fair & $1.1-2$ & Poor \\
\hline III & $57-60$ & Fair & $1.35-3$ & Poor \\
\hline IV & $50-71$ & Fair & $2.4-13.3$ & Poor - Fair \\
\hline V & $56-61$ & Fair & $2.3-9$ & Poor - Fair \\
\hline VI & $58-69$ & Good & $3.92-9$ & Fair \\
\hline VII & $55-60$ & Fair & $3.4-9$ & Poor - Fair \\
\hline VIII & $57-59$ & Fair & $4.3-9$ & Fair \\
\hline IX & $19-21$ & Poor & $0.006-0.015$ & $\begin{array}{c}\text { Exceptionally } \\
\text { Poor - Extremely } \\
\text { poor } \\
\text { Exceptionally }\end{array}$ \\
\hline$x$ & $23-28$ & Poor & $0.006-0.02$ & $\begin{array}{c}\text { Poor - Extremely } \\
\text { poor }\end{array}$ \\
\hline$X I$ & $18-20$ & Poor & $0.37-6$ & Fair \\
\hline XII & $50-64$ & Fair & $2.1-6$ & Poor - Fair \\
\hline XIII & $50-57$ & Fair & $0.95-2$ & Poor \\
\hline XIV & $49-59$ & Fair & $1.1-3$ & Poor \\
\hline$X V$ & $30-35$ & Poor & $0.2-0.4$ & Poor \\
\hline
\end{tabular}

Tab. 3. Primary support estimation for tunnel rock masses

\begin{tabular}{cc}
\hline Rock mass & Primary support \\
\hline $\begin{array}{c}\text { Limestone with dolomite, marl stone, mud stone and } \\
\text { conglomerate }\end{array}$ & Using rock bolt or shotcrete lining by $5 \mathrm{~cm}$ in Thickness. \\
\hline $\begin{array}{c}\text { Crushed limestone and marly limestone, Marly and } \\
\text { shale limestone and Shaly limestone }\end{array}$ & $\begin{array}{c}\text { Application of rock bolt } 2.5 \mathrm{~m} \text { in length with } 1 \times 1 \\
\text { distance together and shotcrete lining by } 5 \mathrm{~cm} \text { or more } \\
\text { in Thickness with mesh and rock bolt }\end{array}$ \\
\hline
\end{tabular}

Tab. 4. Explanation of Model Notations [15]

\begin{tabular}{cc}
\hline Support system (Alternative) & Explanation \\
\hline A & $\begin{array}{r}\text { Supporting by shotcrete lining by } 25 \mathrm{~cm} \text { in thickness } \\
\text { together with IPE18 }\end{array}$ \\
Supporting by shotcrete lining by $30 \mathrm{~cm}$ in thickness \\
together with IPE 16
\end{tabular}

Tab. 5. Classification of squeezing behaviour according to Singh et al.

\begin{tabular}{cc}
\hline$H$ & Type of behaviour \\
\hline$>350 Q^{1 / 3}$ & Squeezing conditions \\
$<350 Q^{1 / 3}$ & Non squeezing conditions \\
\hline
\end{tabular}




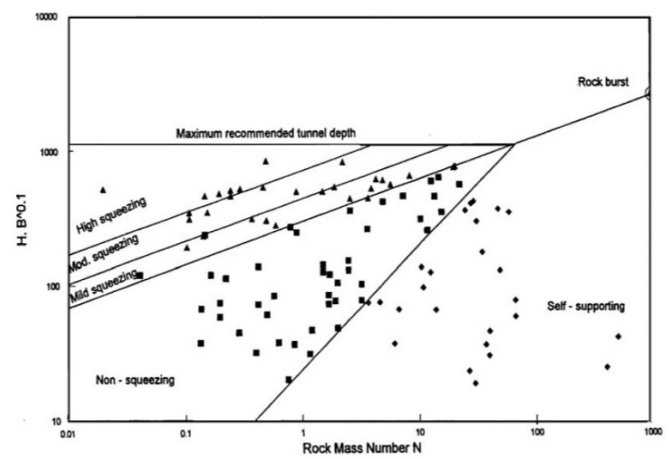

Fig. 1. Goel et al.'s approach for predicting squeezing conditions [3]

3.1.2.1 Jethwa et al. Approach As mentioned above, the degree of squeezing is defined by Jethwa et al. [4] on the basis of Eq. (3) and Table 6 .

$$
N_{c}=\sigma_{c m} / P_{0}=\sigma_{c m} / \gamma H
$$

Where $\sigma_{c m}$ is rock mass uniaxial compressive strength, $P_{0}$ is in situ stress, $\gamma$ is rock mass unit weight and $H$ is the tunnel depth below surface.

Tab. 6. Classification of squeezing behaviour according to Jethwa et al.

\begin{tabular}{cc}
\hline$N_{C}$ & Type of behaviour \\
$0.4>$ & Highly squeezing \\
$0.4-0.8$ & Moderately squeezing \\
$0.8-2$ & Mildly squeezing \\
$>2$ & Non squeezing \\
\hline
\end{tabular}

3.1.2.2 Aydan et al. approach Aydan et al. [20], based on the experience of tunnels in Japan, proposed to relate the strength of the intact rock $\sigma_{c i}$ to the overburden pressure $\gamma H$ by the same relation as (3), implying that the uniaxial compressive strength of the intact rock $\sigma_{c i}$ and that of the rock mass $\sigma_{c m}$ are the same. The fundamental concept of the method is based on the analogy between the stress-strain response of rock in laboratory testing and tangential stress-strain response around tunnels. As illustrated in Fig. 2, five distinct states of the specimen during loading are experienced, at low confining stress $\sigma_{3}$ (i.e., $\sigma_{3} \leq$ $\left.0.1 \sigma_{c i}\right)$. The following relations, as defined, give the normalized strain levels $\eta_{P}, \eta_{s}$ and $\eta_{f}[20]$.

$$
\begin{aligned}
& \eta_{P}=\varepsilon_{P} / \varepsilon_{e}=2 \sigma_{c i}-0.17, \\
& \eta_{s}=\varepsilon_{s} / \varepsilon_{e}=3 \sigma_{c i}-0.25, \\
& \eta_{f}=\varepsilon_{f} / \varepsilon_{e}=5 \sigma_{c i}-0.32
\end{aligned}
$$

Where $\varepsilon_{P}, \varepsilon_{s}$ and $\varepsilon_{f}$ are the strain values shown in Fig. 2, as $\varepsilon_{e}$ is the elastic strain limit.

Based on a closed form analytical solution, which has been developed for computing the strain level $\varepsilon_{\Theta}^{a}$ around a circular tunnel in a hydrostatic stress field, the five different degrees of squeezing are defined as shown in Table 7. In this Table, $\varepsilon_{\Theta}^{a}$ is the tangential strain around a circular tunnel in a hydrostatic stress field [20], whereas $\varepsilon_{\Theta}^{e}$ is the elastic strain limit for the rock mass.

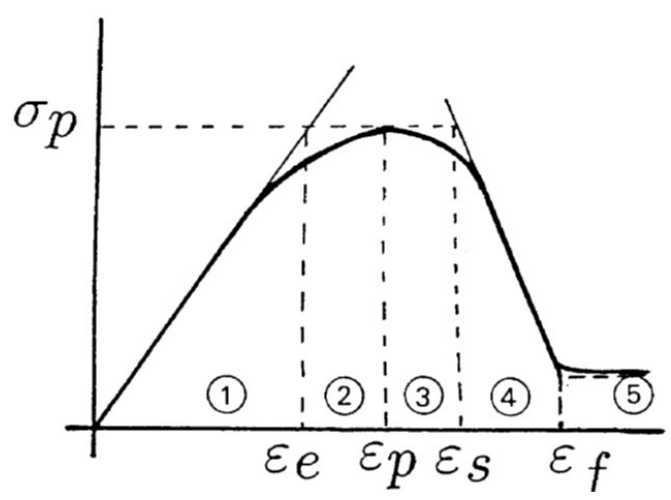

Fig. 2. Idealized stress-strain curve and the associated states for squeezing rocks

Tab. 7. Classification of squeezing behaviour according to Aydan et al.

\begin{tabular}{cc}
\hline Theoretical expression & Squeezing degree \\
\hline$\varepsilon_{\boldsymbol{\Theta}}^{\mathbf{a}} / \varepsilon_{\boldsymbol{\Theta}}^{\mathbf{e}} \leq 1$ & Non-squeezing \\
$1 \leq \varepsilon_{\boldsymbol{\Theta}}^{\mathbf{a}} / \varepsilon_{\boldsymbol{\Theta}}^{\mathbf{e}} \leq \eta_{p}$ & Light-squeezing \\
$\eta_{p} \leq \varepsilon_{\boldsymbol{\Theta}}^{\mathbf{a}} / \varepsilon_{\boldsymbol{\Theta}}^{\mathbf{e}} \leq \eta_{s}$ & Fair-squeezing \\
$\eta_{s} \leq \varepsilon_{\boldsymbol{\Theta}}^{\mathbf{a}} / \varepsilon_{\boldsymbol{\Theta}}^{\mathbf{e}} \leq \eta_{f}$ & Heavy-squeezing \\
$\varepsilon_{\boldsymbol{\Theta}}^{\mathbf{a}} / \varepsilon_{\boldsymbol{\Theta}}^{\mathbf{e}} \geq \eta_{f}$ & Very heavy squeezing \\
\hline
\end{tabular}

\subsubsection{Analytical-Theoretical Approaches}

\subsubsection{Barla and International Society of Rock Mechanics}

(ISRM) Approaches The squeezing potential in these methods can be expected in accordance to Table 8 by considering the values of tangential stress $\left(\sigma_{\Theta}\right)$, uniaxial compressive strength $\left(\sigma_{c m}\right)$ and the maximum stress $\left(\sigma_{1}\right)[18]$.

Tab. 8. Classification of squeezing behaviour according to Barla and ISRM approaches 18

\begin{tabular}{ccc}
\hline \multicolumn{2}{c}{ Evaluation Method } & Squeezing degree \\
ISRM $\left(\sigma_{\theta} / \sigma_{c m}\right)$ & Barla $\left(\sigma_{c m} / \sigma_{1}\right)$ & \\
\hline$<1$ & $>1$ & Non-squeezing \\
$1-2$ & $1-0.4$ & Light-squeezing \\
$2-4$ & $0.4-0.2$ & Fair-squeezing \\
$>4$ & $0.2>$ & Heavy-squeezing \\
\hline
\end{tabular}

\subsection{Evaluation of Squeezing Potential in Beheshtabab Wa- ter Conveyance Tunnel}

The results of assessing squeezing potential for the zone of the tunnel, in which there was the occurrence of this phenomenon using different criteria, have been shown in Fig. 3 To study the result of different criteria, the percentage of each category of the studied squeeze zones was calculated as shown in Table 9 In average, 69, 23, 5 and 3 percent of total panels were in none, light, moderate and heavy squeezing conditions, respectively. So, most sections of the tunnel were in none squeezing potential. 

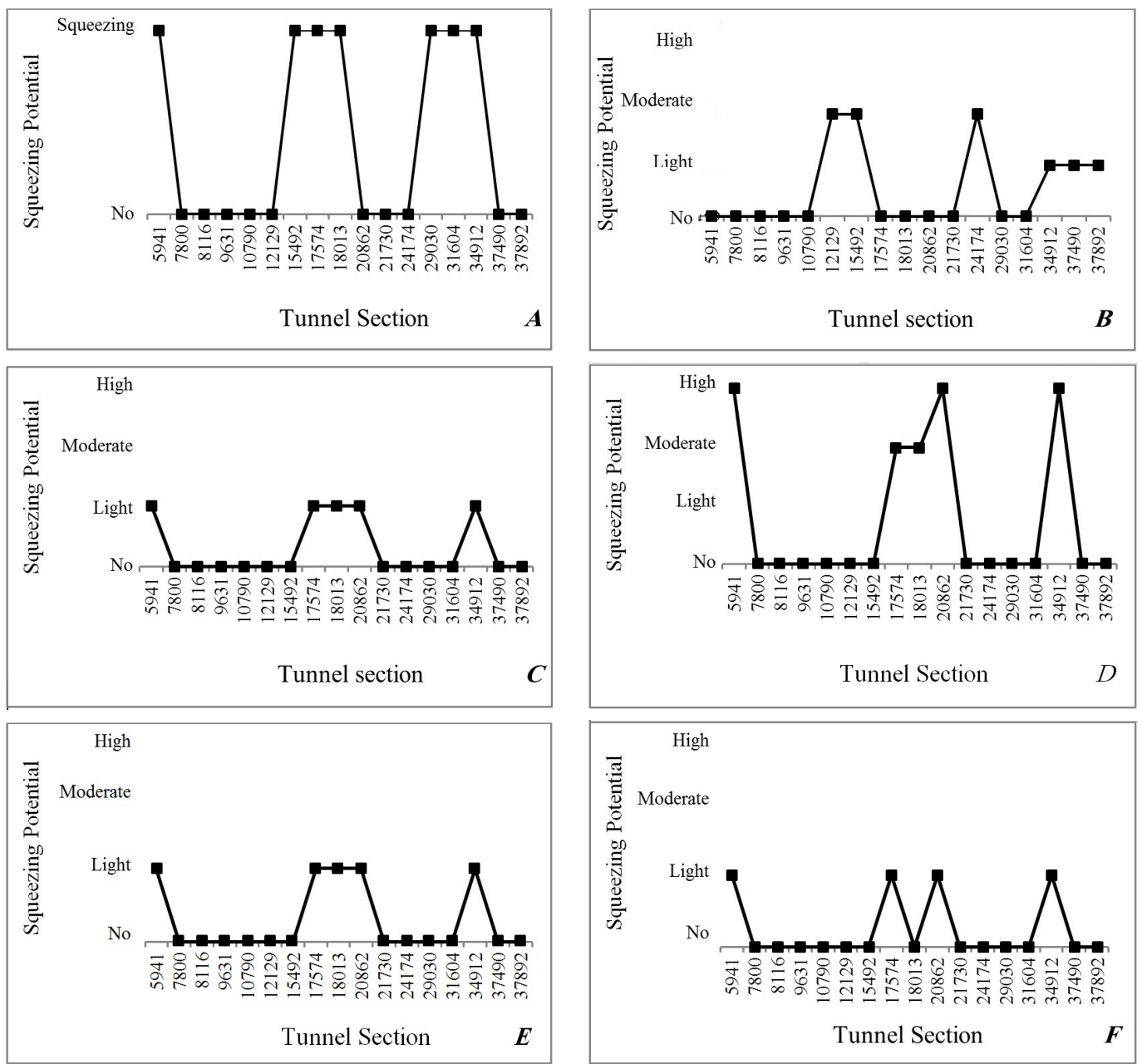

Fig. 3. The results of the squeezing potential using Singh (A), Goel (B), Jethwa (C), Aydan (D), Barla (E) and ISRM (F) criteria
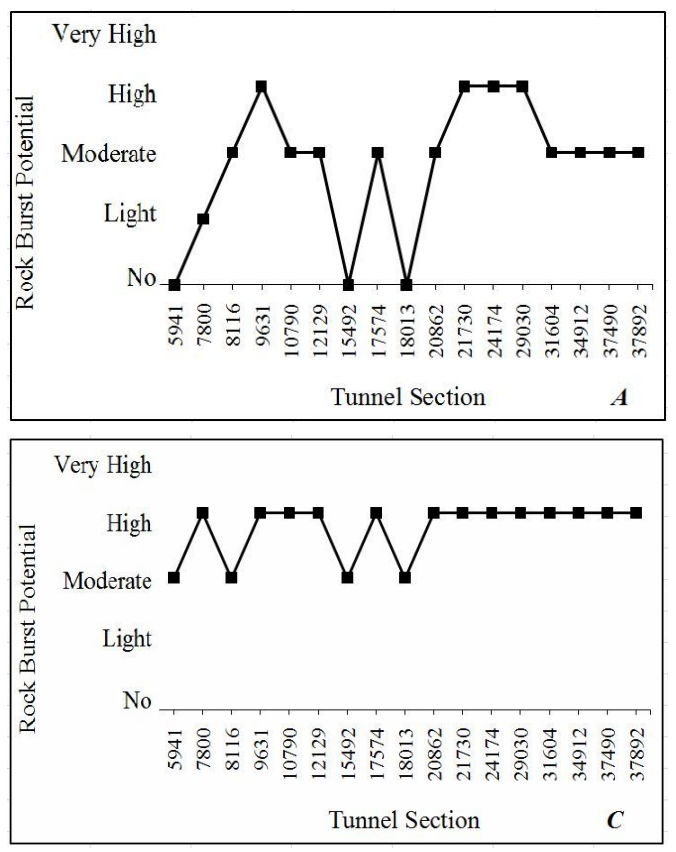

Fig. 4. The results of the rock burst potential using the method of stresses $(A)$, linear elastic criterion $(B)$, brittleness coefficient $(C)$ and tensile stress $(D)$
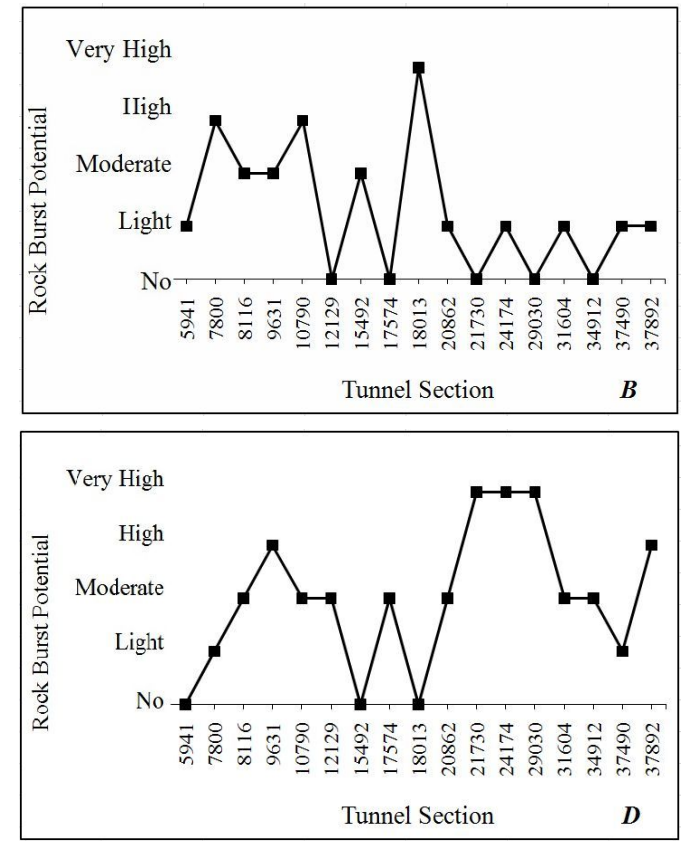

criteria. 
Tab. 9. The results of the squeezing potential in Beheshtabad Water Conveyance Tunnel

\begin{tabular}{ccccc}
\hline & Percentage of tunnel sections in each squeezing condition & \multirow{2}{*}{ Evaluation criteria } \\
\cline { 1 - 4 } Non & Light & Moderate & High & Singh \\
65 & 41 & 0 & 0 & Goel \\
72 & 17 & 17 & 0 & Jethwa \\
72 & 28 & 0 & 17 & Aydan \\
72 & 0 & 11 & 0 & Barla \\
75 & 28 & 0 & 0 & ISRM \\
\hline
\end{tabular}

\section{Rock Burst}

A rock burst is one of the most complicated dynamic geological phenomena, with intricate mechanisms and numerous affecting factors, which accounts for the difficulty of predicting its characteristics. In the past few years, many methods of forecasting rock bursts have been proposed, including the assessment of rock mechanics, stress detection and modern mathematical theories.

The prevention of rock bursts is one of the key problems in the construction of deep tunnels in which rock burst prediction is a basic problem. In the construction of underground engineering, it is of great importance for the safety and the optimization of support measures to make correct and timely predictions of the possibility, as well as the scope and intensity of rock bursts in the rock mass surrounding the excavated ground.

\subsection{Rock Burst Prediction}

Regarding the available and valid references, comprehensive researches have been carried out in the classification and evaluation of rock burst phenomenon. In most of them, linear elastic criterion, method of Tensile Stress, method of Brittleness Coefficient and Method of Stresses have been used for rock burst prediction [7, 21-35]:

\subsubsection{Linear Elastic Criterion}

Linear elastic energy stored in rock before reaching the peak strength can be defined by the Eq.(5] [21].

$$
L E=\frac{\sigma_{c}^{2}}{2 E}
$$

Where LE is the linear elastic energy (MPA), $E$ is unloading tangent elastic modulus of rock, and $\sigma_{c}$ is uniaxial compressive strength. Rock burst potential is predictable by using Table 10

\subsubsection{Method of Tensile Stress}

Rock burst predictions using this method can be defined by Eq. (6). Rock burst potential is predictable by using Table 11 [13].

$$
T_{s}=\frac{\sigma_{\theta}}{\sigma_{c}}
$$

Where $\sigma_{\text {Theta }}$ is the tensile stress, and $\sigma_{c}$ is the uniaxial compressive strength.

\subsubsection{Method of Brittleness Coefficient}

This method evaluates the tendency of rock burst through the brittleness coefficient of Rocks $(\beta)$. This coefficient is defined as the ratio of $\sigma_{c}$ over $\sigma_{t}\left(\sigma_{c}\right.$ and $\sigma_{t}$ are the uniaxial compressive strength and the tensile strength of the rock, respectively), i.e., $\beta=\sigma_{c} / \sigma_{t}$. In general, the grater $\beta$, the higher the rock burst tendency (see Table 12) [22].

\subsubsection{Method of Stresses}

Method of stresses combines the lithological character of a rock mass (including tensile and compressive strength) to judge the possibility that rock burst can take place. This method introduces two factors of $\alpha$ and $\beta$ to serve as criteria. $\alpha$ and $\beta$ are defined, respectively, as the ratio of the rocks uniaxial compressive strength $\left(\sigma_{c}\right)$ over the major principle geo-stress $\left(\sigma_{1}\right)$, i.e., $\alpha=\sigma_{c} / \sigma_{1}$ and as the ratio of the rocks uniaxial tensile strength, $\sigma_{t}$, over $\sigma_{1}$, i.e., $\beta=\sigma_{t} / \sigma_{1}$. Because the index of the uniaxial compressive can be determined easily, the value of $\alpha$ is generally used for a criterion having the following Table [22].

\subsection{Evaluation of Rock Burst Potential in Beheshtabad Wa- ter Conveyance Tunnel}

The results of the rock burst potential assessing for the zone of the tunnel in which the occurrence of this phenomenon was achieved using different criteria, as shown in Fig. 4. To study the Different criteria results, the percentage of each category of studied rock burst zones was calculated as shown in Table 14.

Regarding Table 14. Linear elastic criterion predicts no rock burst potential for more sections of the tunnel, while Tensile Stress and Stresses methods assume the major sections of tunnel to be in the fair rock burst potential. According to brittleness coefficient, all tunnel sections are unfortunately in heavy rock burst condition. In average, 16, 13, 31, 34 and 6 percent of total panels are in none, light, moderate, heavy and very heavy rock burst conditions, respectively. So, most sections of tunnel are in moderate to high rock burst condition. To have a better comparison, the obtained results have been shown in Fig. 5 Also, to better understand, the results were given in Table 15 . Regarding Fig. 5 and Table 15, more of the sections are in high squeezing potential condition. So, in this tunnel, the squeezing potential is more important than the rock burst. These results are in agreement with high overburden and weak sedimentary rock masses in these sections. 
Tab. 10. Classification of Rock burst behaviour according to linear elastic criterion

\begin{tabular}{cccccc}
\hline $50>$ & $50-100$ & $100-150$ & $150-200$ & $200<$ & $L E(\mathrm{MPa})$ \\
\hline Very Low & Low & Moderate & High & Very High & $\begin{array}{c}\text { Rock burst } \\
\text { potential }\end{array}$ \\
\hline
\end{tabular}

Tab. 11. Classification of Rock burst behavior according to the Method of Tensile Stress

\begin{tabular}{cccccc}
\hline $0.3>$ & $0.3-0.5$ & $0.5-0.7$ & $0.7-0.9$ & $0.9<$ & $T_{S}$ \\
\hline \multirow{2}{*}{ Non } & Low & Moderate & High & Very High & $\begin{array}{c}\text { Rock burst } \\
\text { potential }\end{array}$ \\
\hline
\end{tabular}

Tab. 12. Classification of Rock burst behaviour according to the method of brittleness coefficient

\begin{tabular}{ccccc}
\hline $40<$ & $40-26.7$ & $26.7-14.5$ & $14.5>$ & $\beta$ \\
\hline Non & Low & Moderate & High & Rock burst potential \\
\hline
\end{tabular}

Tab. 13. Classification of Rock burst behaviour according to the Method of Stresses

\begin{tabular}{ccccc}
\hline $10<$ & $10-5$ & $5-2.5$ & $2.5>$ & $\alpha$ \\
\hline Non & Low & Moderate & High & Rock burst potential \\
\hline
\end{tabular}

Tab. 14. The results of the rock burst potential

\begin{tabular}{|c|c|c|c|c|c|}
\hline \multicolumn{6}{|c|}{$\begin{array}{l}\text { Percentage of } \\
\text { tunnel sections } \\
\text { in each of rock } \\
\text { burst conditions }\end{array}$} \\
\hline Non & Light & Moderate & High & Very high & $\begin{array}{c}\text { Evaluation } \\
\text { criteria }\end{array}$ \\
\hline 18 & 6 & 53 & 23 & 0 & Stresses \\
\hline 29 & 35 & 18 & 12 & 6 & $\begin{array}{c}\text { Linear elastic } \\
\text { criterion }\end{array}$ \\
\hline 0 & 0 & 12 & 88 & 0 & $\begin{array}{l}\text { Brittleness } \\
\text { coefficient }\end{array}$ \\
\hline 18 & 12 & 41 & 12 & 17 & Tensile Stress \\
\hline
\end{tabular}

Tab. 15. The results of squeezing and rock burst potential in the tunnel sections

\begin{tabular}{lccccc}
\hline & \multicolumn{5}{c}{ Percentage of tunnel sections in each of rock burst and Squeezing conditions (\%) } \\
\hline & Non & Light & Moderate & High & Very High \\
Squeezing & 69 & 23 & 5 & 3 & 0 \\
Rock burst & 16 & 13 & 31 & 34 & 6 \\
\hline
\end{tabular}




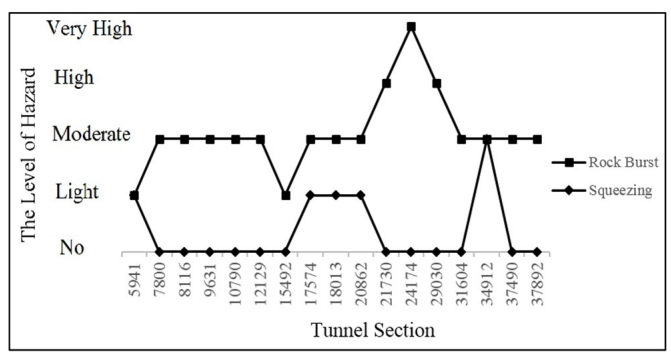

Fig. 5. Comparison of the squeezing and rock burst potential results

\section{Conclusions}

Squeezing and rock burst potential were addressed in this article using different empirical, semi-empirical and analytical approaches. The results showed that empirical and analytical methods were almost accommodated with each other. In squeezing potential research, according to Singh, Jethwa, Barla and ISRM approaches, a great numbers of tunnel sections fell into non-squeezing potential category. Aydan and Goel criteria, similar to the recently mentioned approaches, have predicted moderate to heavy squeezing potential for a small percentage of sections. Based on our researches, the results showed that 69, 23, 5 and 3 percent of total panels were in none, light, moderate and heavy squeezing conditions, respectively. Thus, the rock masses in this tunnel path were in none to light squeezing potential. In rock burst potential research, according to forbear Linear Elastic Criterion that predicted moderate rock burst potential for all sections, 16, 13, 31, 34 and 6 percent of total panels were in none, light, moderate, heavy and very heavy rock burst conditions noticeability by referring back other methods of Tensile Stress, Tensile Stress and Method of Stresses. So, the rock masses in this tunnel path were in moderate to high rock burst potential. According to the precise prediction of this phenomena, it is not possible to have a safe environment during the deep exploration and mining. So, some necessary measure of prevention are proposed:

1 The construction methods can be improved. The impact of blasting vibration should be minimized as far as possible to avoid bringing about various factors inducing rock burst.

2 Rock can be strengthened by grouting to change the mechanical properties of the wall rock. Grouting bolt nets and plastic bolts can also be applied to the underground chamber or wall rock.

3 In very poor squeezing conditions, using heavy support and monitoring the displacements of the roof and bottom of the tunnel and using flexible support in moderate to high squeezing conditions are essential.

\section{References}

1 Palmström A, Characterizing rock burst and squeezing by the rock mass index, In: International conference in design and construction of underground structures, Vol. 10, 1995.
2 Singh B, Jethwa JL, Dube AK, Singh B, Correlation between observed support pressure and rock mass quality, Tunnelling and Underground Space Technology, 7(1), (1992), 59-74, DOI 10.1016/0886-7798(92)90114-W

3 Goel RK, Jethwa JL, Paithankar AG, Tunnelling through the young $\mathrm{Hi}$ malaya's case history of the Maneri-Uttarkashi power tunnel, Engineering Geology, 39(1), (1995), 31-44, DOI 10.1016/0013-7952(94)00002-J

4 Jethwa JL, Singh B, Singh B, Estimation of ultimate rock pressure for tunnel linings under squeezing rock conditions-a new approach, In: Brown $\mathbf{E}$ T, Hudson J A (eds.), Design and Performance of Underground Excavations, ISRM Symposium, 1984, pp. 231-238.

5 Hoek E, Marinos P, Predicting tunnel squeezing problems in weak heterogeneous rock masses, Tunnels and tunnelling international, 32(11), (2000), 45-51, http://citeseerx.ist.psu.edu/viewdoc/download? doi=10.1.1.474.7992\&rep=rep1\&type=pdf

6 Hoek E, Marinos P, Predicting tunnel squeezing problems in weak heterogeneous rock masses, Tunnels and tunnelling international, 32(11), (2000), 45-51.

7 Jiang Q, Feng X-T, Xiang T-B, Su G-S, Rockburst characteristics and numerical simulation based on a new energy index: a case study of a tunnel at 2,500 $\mathrm{m}$ depth, Bulletin of engineering geology and the environment, 69(3), (2010), 381-388, DOI 10.1007/s10064-010-0275-1

8 Hoek E, Brown ET, Underground excavations in rock, 1980.

9 Myrvang A, Grimstad E, Rockburst problems in Norwegian Highwaytunnels recent case histories, In: Rockbursts Prediction and Control, Institute of Mines and Metallurgy London, 1983, pp. 133-139.

10 Hatcher RD, Structural geology: Principles, concepts, and problems, Macmillan Publishing Company, 1995.

11 Haramy KY, Underground structures in rock bursts zones, Elsevier, 1998.

12 Qiao CS, Tian ZY, Study of the possibility of rockburst in Donggua-shan Copper Mine, Chinese J. Rock Mech. Eng. Žexp, 17, (1998), 917-921.

13 Wang J-A, Park HD, Comprehensive prediction of rockburst based on analysis of strain energy in rocks, Tunnelling and Underground Space Technology, 16(1), (2001), 49-57, DOI 10.1016/S0886-7798(01)00030-X

14 Amberg F, Tunnelling in high overburden with reference to deep tunnels in Switzerland, Tunnelling and Underground Space Technology, 19(4), (2004), 308-308, DOI 10.1016/j.tust.2004.01.009

15 Rafiee R, Ataei M, Jalali SME, The optimum support selection by using fuzzy analytical hierarchy process method for Beheshtabad water transporting tunnel in Naien, Iranian Journal of Fuzzy Systems, 10(6), (2013), 39-51.

16 Hashemi M, Rock mechanics reports, Water Supply Project of the Central Plateau, Zayandeab Consulting, 2007.

17 Rahimdel MJ, Mahdevari S, Bagherpour R, Stability Assessments and Support Estimation of Beheshtabad Water Transport Tunnel by VNIMI Method, In: The 1st Asian and 9th Iranian Tunneling Symposium, 2011.

18 Barla G, Tunnelling under squeezing rock conditions, Eurosummer-School in Tunnel Mechanics, Innsbruck, (2001), 169-268.

19 Seifabad MC, Sadrnejad SA, Ebrahimi D, A Study of Swelling Behaviour in a Tunnel Using Finite Element Methods, Periodica Polytechnica Civil Engineering, 59(2), (2015), 103-107, DOI 10.3311/PPci.7538

20 Aydan Ö, Akagi T, Kawamoto T, The squeezing potential of rocks around tunnels; theory and prediction, Rock Mechanics and Rock Engineering, 26(2), (1993), 137-163, DOI 10.1007/BF01023620

21 Kwasniewski M, Szutkowski I, Wang JA, Study of ability of coal from seam 510 for storing elastic energy in the aspect of assessment of hazard in Porabka-Klimontow Colliery, Sci. Rept. Silesian Technical University, (1994).

22 Guang Z, Jingxi C, Bin H, Prediction and Control of Rockburst during Excavation of a Gold Mine In China, Chinese Journal of Rock Mechanics and Engineering, 10(22), (2003), 1607-1612.

23 Casten U, Fajklewicz Z, Induced gravity anomalies and rock-burst risk in 
coal mines: a case history, Geophysical prospecting, 41(1), (1993), 1-13, DOI $10.1111 / j .1365-2478.1993 . t b 00562 . x$

24 Shivakumar K, Rao MVMS, Srinivasan C, Kusunose K, Multifractal analysis of the spatial distribution of area rockbursts at Kolar Gold Mines, In: International journal of rock mechanics and mining sciences \& geomechanics abstracts, Vol. 33, Elsevier, 1996, pp. 167-172.

25 Linkov AM, Rockbursts and the instability of rock masses, In: International journal of rock mechanics and mining sciences \& geomechanics abstracts, Vol. 33, Elsevier, 1996, pp. 727-732, DOI 10.1016/0148-9062(96)00021-6

26 Sharan SK, A finite element perturbation method for the prediction of rockburst, Computers \& Structures, 85(17), (2007), 1304-1309, DOI 10.1016/j.compstruc.2006.08.084

27 Hong-Bo Z, Classification of rockburst using support vector machine, Rock and Soil Mechanics, 26(4), (2005), 642-644.

28 Gong F, Li X, A distance discriminant analysis method for prediction of possibility and classification of rockburst and its application., Yanshilixue $\mathrm{Yu}$ Gongcheng Xuebao/Chinese Journal of Rock Mechanics and Engineering, 26(5), (2007), 1012-1018.

29 Zhu WC, Li ZH, Zhu L, Tang CA, Numerical simulation on rockburst of underground opening triggered by dynamic disturbance, Tunnelling and Underground Space Technology, 25(5), (2010), 587-599, DOI 10.1016/j.tust.2010.04.004

30 Wang YC, Shang YQ, Sun HY, Yan X-S, Study of prediction of rockburst intensity based on efficacy coefficient method, Rock and Soil Mechanics, 31(2), (2010), 529-534.

31 Yang J, Li X, Zhou Z, Lin Y, A Fuzzy assessment method of rock-burst prediction based on rough set theory, Jinshu Kuangshan/Metal Mine, 6, (2010), 26-29.

32 Zhou J, Shi X-z, Dong L, Hu H-y, Wang H-y, Fisher discriminant analysis model and its application for prediction of classification of rockburst in deepburied long tunnel, Journal of Coal Science and Engineering (China), 16(2), (2010), 144-149, DOI 10.1007/s12404-010-0207-5

$33 \mathrm{He} \mathbf{H}$, Dou L, Li X, Qiao Q, Chen T, Gong S, Active velocity tomography for assessing rock burst hazards in a kilometer deep mine, Mining Science and Technology (China), 21(5), (2011), 673-676, DOI 10.1016/j.mstc.2011.10.003

34 Chen X, Li W, Yan X, Analysis on rock burst danger when fully-mechanized caving coal face passed fault with deep mining, Safety science, 50(4), (2012), 645-648, DOI 10.1016/j.ssci.2011.08.063

35 Fan J, Dou L, He H, Du T, Zhang S, Gui B, Sun X, Directional hydraulic fracturing to control hard-roof rockburst in coal mines, International Journal of Mining Science and Technology, 22(2), (2012), 177-181, DOI 10.1016/j.ijmst.2011.08.007 